\title{
The influence of iron supplementation in pregnant women to the occurrence of low birth weight (LBW) babies in Palu, Central Sulawesi
}

\author{
Sri Restu', Djaswadi Dasuki ${ }^{2}$, R. Detty Siti Nurdiati $Z^{2}$ \\ ${ }^{1}$ Health Polytechnic of Palu, Central Sulawesi, ${ }^{2}$ Department of Obstetrics and \\ Gynecology, Dr. Sardjito Hospital, Yogyakarta
}

\section{ABSTRACT}

Low birth weight (LBW) babies remains a major problem world wide as it causes a high rate of neonatal morbidity and mortality. One effort to reduce the prevalence of LBW babies is by providing iron supplementation to the pregnant women. The aim of this study was to examine the relationship between iron supplementation program and prevalence of LBW babies in Palu, Central Sulawesi. This was an observational study with case control design. Subjects were all LBW babies from mothers that had accepted iron supplementation during pregnancy. Sample size in this study was 87 for case and 87 for control. Bivariate analysis showed that iron supplementation that not comply the program had a significant correlation with prevalence of LBW babies $(p=0.01)$. Other significant factors include abnormal hemoglobin level $(p=0.01)$, body mass index (BMI) $(p=0.02)$, educational level $(p=0.02)$, multiparity $(p=0.03)$, and gestational age (prematurity) $(p=0.03)$. Multivariate analysis revealed that the strongest risk factor for the occurrence of LBW babies was iron supplementation that not comply the program $(O R=3.82 ; 95 \% \mathrm{Cl}: 1.77-8.22)$. Other risk factors were hemoglobin level $(\mathrm{OR}=3.45 ; 95 \% \mathrm{Cl}:$ 1.59-7.49), $\mathrm{BMI}(\mathrm{OR}=2.27 ; 95 \% \mathrm{Cl}: 1.05-4.91)$, gestational age $(\mathrm{OR}=3.11 ; 95 \% \mathrm{Cl}: 1.45-$ 6.67), multiparity $(\mathrm{OR}=2.98,95 \% \mathrm{Cl}: 1.36-6.51)$, and educational level $(\mathrm{OR}=2.38,95 \% \mathrm{Cl}$ : $1.12-5.03)$. Based on the analysis, the strongest risk factors that affected the prevalence of LBW was iron supplementation, abnormal hemoglobin level, gestational age, multiparity and education level. In conclusion, iron supplementation during pregnancy that not comply with the program was the strongest risk factor of LBW babies. The prevalence of LBW babies can be reduced by controlling of iron supplementation, hemoglobin level, BMI, gestational age, parity and education.

\section{ABSTRAK}

Bayi dengan berat badan lahir rendah (BBLR) tetap menjadi masalah kesehatan di seluruh dunia karena penyebab tingginya morbiditas dan mortalitas neonatus. Salah satu usaha menurunkan prevalensi BBLR adalah memberikan suplemen besi pada ibu hamil. Penelitian ini bertujuan mengkaji hubungan antara program suplementasi besi dengan prevalensi bayi dengan BBLR di Palu, Sulawesi Tengah. Penelitian ini adalah penelitian observasi dengan rancangan kasus kontrol. Subyek penelitian adalah semua bayi dengan BBLR dari ibu yang menerima suplementasi besi selama hamil dengan jumlah sampel 87 kasus dan 87 kontrol. Analisis bivariat menunjukkan bahwa suplementasi besi yang tidak sesuai dengan program mempunyai hubungan nyata dengan kejadian bayi dengan BBLR $(p=0,01)$. Faktor lain yang berpengaruh nyata adalah kadar hemoglobin rendah $(p=0,01)$, indeks masa tubuh (IMT) rendah, pendidikan rendah $(p=0,02)$, multiparitas lebih dua kali persalinan $(p=0,03)$ dan kelahiran prematur $(p=0,03)$. Analisis bivariat menunjukkan bahwa suplementasi besi yang tidak sesuai program berhubungan nyata dengan prevalensi bayi dengan $\operatorname{BBLR}(p=0,01)$. Faktor risiko lain yang berpengaruh IMT $(p=0,02)$, tingkat pendidikan $(p=0,02)$,

\footnotetext{
* corresponding author: restu_ikkmp@yahoo.com
} 


\begin{abstract}
multiparitas $(p=0.03)$ dan umur kehamilan $(p=0.03)$. Analisis multivariat menunjukkan bahwa faktor risiko paling kuat terjadinya bayi dengan BBLR adalah suplementasi besi yang tidak mengikuti program $(\mathrm{OR}=3,82 ; 95 \% \mathrm{Cl}: 1,77-8,22)$. Faktor risiko lain adalah kadar hemoglobin $(\mathrm{OR}=3,45 ; 95 \% \mathrm{Cl}: 1,59-7,49)$, IMT (OR = 2,27; 95\% Cl: 1,05-4,91), umur kehamilan $(\mathrm{OR}=$ $3,11 ; 95 \% \mathrm{Cl}: 1,45-6,67)$, multiparitas (OR $=2,98,95 \% \mathrm{Cl}: 1,36-6,51)$, dan tingkat pendidikan $(\mathrm{OR}=2,38 ; 95 \% \mathrm{Cl}: 1,12-5,03)$. Berdasarkan analisis tersebut, faktor risiko terkuat yang mempengaruhi prevalensi bayi dengan BBLR adalah suplementasi besi, kadar hemoglobin, masa kehamilan, multiparitas dan tingkat pendidikan. Dapat disimpulkan bahwa suplementasi besi selama kehamilan yang tidak sesuai program yang ditetapkan merupakan faktor risiko terkuat terjadinya bayi dengan BBLR. Prevalensi bayi dengan BBLR dapat diturunkan dengan mengontrol suplementasi besi, kadar hemoglobin, IMT, masa kehamilan, paritas dan pendidikan.
\end{abstract}

Keywords: iron supplementation - pregnant women - LBW babies

\section{INTRODUCTION}

Low birth weight (LBW) babies are considered as a major problem worldwide as it causes a high rate of neonatal morbidity and mortality. Nowadays, the prevalence of LBW babies is still high, especially in countries with low socioeconomic level. Statistically, $90 \%$ of LBW babies were found in developing countries with a 3.5 greater mortality rate as compared to newborns with birth weight of $>2500$ grams. ${ }^{1}$ The incidences of LBW babies in Indonesia are widely varied, with the range of 9-30\%. LBW babies are defined as babies born with weight of less than 2500 grams as measured within 72 hours after birth, while a preterm birth was defined as a birth that occurs before a gestational age of 37 weeks. $^{1}$

World Health Organization estimated that among 20 millions of LBW babies born each year, 19 millions were born in developing countries. ${ }^{2}$ The prevalence of LBW babies in Indonesia was estimated to be 2.1-17.2\%. In the end of REPELITAV, the prevalence of LBW babies was $15 \%$ and was expected to decrease to $10 \%$ by the end of REPELITA VI. The case of LBW babies is crucial since it correlates with the health status of the fetus and the ability to survive in the future. ${ }^{3}$ One of the results of Declaration of United Nation Session on Children (2002) was to decrease the incidence of LBW babies by at least one-third during the year 2000-2010 and to conduct the efforts to prevent the occurrence of LBW babies by antenatal care UNICEF \& WHO. ${ }^{4}$

One hundred and six (9\%) LBW babies were reported in Palu in 2007 while the coverage achievement of $\mathrm{Fe} 1$ and $\mathrm{Fe} 3$ were $83.76 \%$ and $75.29 \%$, respectively. The stillexist occurrence of LBW babies may be caused by the inadequate quality of obstetric service standard, as shown by the coverage of iron supplementation that had not achieved $100 \%$, yet and the gap of antenatal care in the fourth visit (K4) of $93.96 \% .^{5}$

It is reported that anemic pregnant women had twice the risk of preterm labor, and were three times more likely to deliver LBW babies and suffered from maternal mortality. ${ }^{6}$ When the pregnant women's hemoglobin level decreased to below $11 \mathrm{gr} / \mathrm{dL}$ during the third trimester, it might affect the fetus in the uterus. ${ }^{6}$ To overcome this problem, an iron tablet supplementation program is conducted to provide tablets of 60 $\mathrm{mg}$ ferous sulphate and $0.25 \mathrm{mg}$ folic acid to pregnant women, to fulfill the need of iron during pregnancy. The supply of iron tablets for prevention is one tablet a day for a minimum of 90 days during pregnancy up to 42 days after delivery. ${ }^{7}$ 
The benefits of iron tablet supplementation program have been reported by some authors. Yip reported generally iron supplementations were provided to pregnant women to decrease the incidence of anemia. ${ }^{8}$ Moreover, Allen suggested that pregnant women should be provided with routine iron supplementation during pregnancy and some days post partum in order to prevent the mothers from experiencing iron deficiency anemia during pregnancy. ${ }^{9}$

Iron deficiency during pregnancy may cause damage or delay in fetal growth in both body cells and brain cells. It may also cause intrauterine fetal death, abortion, congenital defects, low birth weight, and anemia in delivered babies. These could lead to increased maternal morbidity and mortality, as well as an increase in perinatal death. ${ }^{10}$

Iron supplementation for pregnant women are highly needed to support fetal growth and maternal health during pregnancy. Early evaluation is carried out to determine the appropriate number of iron tablets consumed by pregnant women during pregnancy, and whether it has met the requirement of e" 90 tablets. The iron supplementation program is an effort of the government to fulfill the iron need of pregnant women, in order to fully support the growth and development of fetus. ${ }^{7}$

Low birth weight babies and the low coverage of iron supplementation are a serious problem in Palu. This research was conducted to evaluate the relationship between iron supplementation and the incidence of low birth weight babies in Palu, Central Sulawesi.

\section{MATERIALS AND METHODS}

\section{Subjects}

This was a case control study with analytical observational design. The study was conducted in the territory of Primary Health Centers (PHCs) in Palu, namely Birobuli
Primary Health Center, Mabelopura Primary Health Center, Singgani Primary Health Center, Kamonji Primary Health Center, and Talise Primary Health Center. The considerations for choosing these locations were based on 1) antenatal examination of pregnant women and providing of iron supplementation as well as newborn examination continuously conducted in these centers; 2) evaluation of iron supplementation program for pregnant never conducted before in theses center; 3) the incidence of LBW babies still observed; 4) coverage of iron supplementation program not achieved. The research population was the babies born within the period ranging from June 2006 to January 2009 in the research locations. Inclusion criteria of the study were LBW babies who were born by health mothers consuming iron tablets during pregnancy, willing to participate in the study and having a health card (Kartu Menuju Sehat $=$ KMS), while the exclusion criteria were babies who were born by mother suffering diseases/complications during pregnancy such as hipertension, malaria and other infections. The total number of samples was 174 with the ratio between the case and the control groups of $1: 1$, therefore the sample size of each group was 87 subjects. ${ }^{11}$ The protocol was approved by the Health Research Ethics Committee of the Faculty of Medicine, Universitas Gadjah Mada, Yogyakarta number KE/FK/118/EC.

\section{Procedures}

The research was started with identifying outcomes in case group (the group of LBW babies) and the control group [the group of normal birth weight (NBW) babies] at the time of delivery from the mothers that consumed iron supplements according to program ( $\geq 90$ tablet) or not in accordance to program ( $<90$ tablet). Data were collected retrospectively to assess the extent of effect of past exposure to current research. ${ }^{12}$ The procedures of the study is presented in FIGURE 1. 


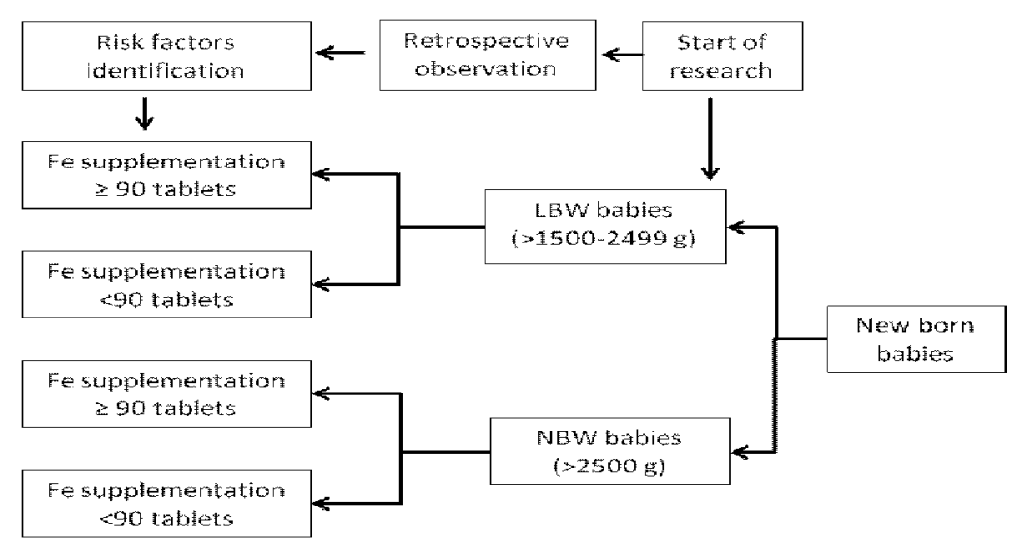

FIGURE 1. The scheme of the research procedure

\section{Statistical analysis}

The data was obtained using a research questionnaire. Bivariate analysis using Chi Square test was conducted to determine the correlation between iron supplementation and the incidence of LBW babies, and other variables i.e. gestational age, hemoglobin level, body mass index (BMI), parity, and level of education. Multivariate analysis was also applied to determine the strength of correlation between outside variables and dependent variables, which were measured simultaneously using the value of odds ratio (OR) and logistic regression analysis test in modeled form, with significance value of $\mathrm{p}<0.05$, and $95 \% \mathrm{CI}$.

\section{RESULTS}

Univariate analysis of characteristics of subjects based on distribution of frequency is presented in TABLE 1. It was found that the number of LBW babies with iron supplemen- tation that was not in accordance with the program was $56(64.3 \%)$, while in the control group (normal birth weight babies) was 39 (44.8\%). The respondents' distribution in the case group with LBW with inadequate gestational age at time of delivery was found to be $44(50.5 \%)$, and $30(34.4 \%)$ in the normal babies control group. The distribution of respondens characteristics in the case group of LBW babies was found to be 48 (55.1\%) for respondens with low BMI category (under weight) while in the control group, it was found to be 33 babies (37.9\%). The abnormal level of hemoglobin was found in 46 respondents $(52.8 \%)$ of case group, and $30(34.5 \%)$ in the control group. The number of LBW babies with risky parity was $41(47.1 \%)$ and in the control group, it was $27(31.0 \%)$. The characteristics of respondents' parents in the case group of LBW babies showed that $49(56.3 \%)$ of them had low education level, and $34(39.0 \%)$ in the control group had high education level. 
Restu et al., The influence of iron supplementation in pregnant women to the occurrence of low birth weight (LBW) babies in Palu, Central Sulawesi

TABLE 1. Distribution of respondent's characteristics

\begin{tabular}{|c|c|c|c|}
\hline \multirow[t]{2}{*}{ Characteristics } & \multicolumn{2}{|c|}{ Birth Weight (gram) } & \multirow{2}{*}{$\begin{array}{c}\text { total } \\
\mathrm{n}=87(\%)\end{array}$} \\
\hline & $\begin{array}{c}\text { LBW Babies } \\
n=87(\%)\end{array}$ & $\begin{array}{c}\text { Normal Babies } \\
n=87(\%)\end{array}$ & \\
\hline \multicolumn{4}{|l|}{ Suplementation } \\
\hline - Appropriate & $56(64.3)$ & $39(44.8)$ & $95(54.6)$ \\
\hline - Inapproprate & $21(35.7)$ & $48(55.2)$ & $79(45.4)$ \\
\hline \multicolumn{4}{|l|}{ Gestational Age } \\
\hline - Inadcquatc & $44(50.5)$ & $30(34.5)$ & $74(42.5)$ \\
\hline - Adequqle & $43(49.5)$ & $57(65.5)$ & $100(57.5)$ \\
\hline \multicolumn{4}{|l|}{ Body Mass Index } \\
\hline - Underweight & $48(55.1)$ & $33(37.9)$ & $81(46.6)$ \\
\hline - Normal & $39(44.2)$ & $54(62.1)$ & $93 .(53.4)$ \\
\hline \multicolumn{4}{|l|}{ Hemoglobin Level } \\
\hline - Abnormal & $46(52.8)$ & $30(34.5)$ & $76(43.7)$ \\
\hline - Normal & $41(47.1)$ & $57(65.5)$ & $98(56.3)$ \\
\hline \multicolumn{4}{|l|}{ Parity } \\
\hline - Risky & $41(47.1)$ & $27(31.0)$ & $68(39.0)$ \\
\hline - Non risky & $46(52.9)$ & $60(67.0)$ & $106(61.0)$ \\
\hline \multicolumn{4}{|l|}{ Education level } \\
\hline - Low & $49(56.3)$ & $34(39.0)$ & $83(47.7)$ \\
\hline - High & $38(43.7)$ & $53(61.0)$ & $91(52.30)$ \\
\hline
\end{tabular}

TABLE 2 presents the result of statistical analysis of the correlation between iron supplementation and the occurrence of LBW babies. A significant difference in the correlation between ion supplementation and the occurrence of LBW was observed in this study $(\mathrm{OR}=2.22 ; 95 \% \mathrm{CI}=1.15-4.28 ; \mathrm{p}=0.00)$. This result showed that the overall incidence of LBW babies was more prevalent in babies whose mother did not apply adequate iron supplementation according to the program ( $<90$ tablets). The risk of having LBW babies were 2.22 times higher in pregnant mothers who did not take the iron supplements as suggested by program ( $\geq$ 90 tablets). The occurrence of LBW babies could be decreased if more strict control of the iron supplementation program was employed entirely in pregnant women.

TABLE 2. Correlation of independent variable (iron supplementation) and dependent variable (LBW babies)

\begin{tabular}{|c|c|c|c|c|c|c|}
\hline \multirow[b]{2}{*}{ Variable } & \multicolumn{2}{|c|}{ Birth Weight (gram) } & \multirow[b]{2}{*}{$\chi^{2}$} & \multicolumn{3}{|c|}{ Statistic Test Results } \\
\hline & $\begin{array}{c}\text { LBW Babies } \\
n=87(\%)\end{array}$ & $\begin{array}{c}\text { Normal Babies } \\
n=87(\%)\end{array}$ & & $\mathrm{p}$ & OR & $95 \% \mathrm{CI}$ \\
\hline \multicolumn{7}{|c|}{ Iron Suplementation } \\
\hline - Appropriate & $56(64.37)$ & $39(44.83)$ & 67 & $000 *$ & 222 & 15428 \\
\hline - Inapproprate & $31(35.63)$ & $48(55.17)$ & 0.7 & 0.00 & $2 . \angle 2$ & $1.15-4.20$ \\
\hline
\end{tabular}

The relationship between confounding variables i.e gestational age, BMI, hemoglobin level, parity, level of education with the incidence of LBW babies is presented in TABLE 3. 
TABLE 3. The relationship between confounding variables and LBW babies

\begin{tabular}{|c|c|c|c|c|c|c|}
\hline \multirow[b]{2}{*}{ Variable } & \multicolumn{2}{|c|}{ Birth Weight (gram) } & \multirow[b]{2}{*}{$\chi^{2}$} & \multicolumn{3}{|c|}{ Statistic Test Results } \\
\hline & $\begin{array}{c}\text { LBW Babies } \\
n=87(\%)\end{array}$ & $\begin{array}{c}\text { Normal Babies } \\
\mathrm{n}=87(\%)\end{array}$ & & $\mathrm{p}$ & OR & $95 \% \mathrm{CI}$ \\
\hline \multicolumn{7}{|l|}{ Hemoglobin level } \\
\hline - Abnormal & $46(52.87)$ & $30(35.5)$ & \multirow{2}{*}{5.98} & \multirow{2}{*}{$0.01 *$} & \multirow{2}{*}{2.13} & \multirow{2}{*}{$1.10-4.11$} \\
\hline - Normal & $41(47.13)$ & $57(65.5)$ & & & & \\
\hline \multicolumn{7}{|l|}{ BMI } \\
\hline - Underweight & $48(55.17)$ & $33(37.9)$ & \multirow{2}{*}{5.20} & \multirow{2}{*}{$0.02 *$} & \multirow{2}{*}{2.01} & \multirow{2}{*}{$1.05-3.86$} \\
\hline - Normal weight & $39(44.83)$ & $54(62.1)$ & & & & \\
\hline \multicolumn{7}{|l|}{ Educational level } \\
\hline - Low & $49(56.32)$ & $34(39.1)$ & \multirow{2}{*}{5.18} & \multirow{2}{*}{$0.03 *$} & \multirow{2}{*}{2.01} & \multirow{2}{*}{$1.05-3.84$} \\
\hline - High & $38(43.86)$ & $53(60.9)$ & & & & \\
\hline \multicolumn{7}{|l|}{ Parity } \\
\hline - Risky & $41(47.13)$ & $27(31.0)$ & \multirow{2}{*}{4.73} & \multirow{2}{*}{$0.03 *$} & \multirow{2}{*}{1.98} & \multirow{2}{*}{$1.01-3.86$} \\
\hline - Non Risky & $46(52.87)$ & $60(68.0)$ & & & & \\
\hline \multicolumn{7}{|l|}{ Gastational age } \\
\hline - Inadequate & $44(50.57)$ & $30(34.5)$ & \multirow{2}{*}{4.61} & \multirow{2}{*}{$0.03^{*}$} & \multirow{2}{*}{1.94} & \multirow{2}{*}{$1.01-3.74$} \\
\hline - Adequate & $43(49.43)$ & $57(65.5)$ & & & & \\
\hline
\end{tabular}

- significantly different with Chi-square test $(p<0.05)$

The result showed that the incidence of LBW babies was associated with the abnormal hemoglobin level $(\mathrm{OR}=2.13 ; 95 \% \mathrm{CI}=1.10-4.11$; $\mathrm{p}=0.01)$, body under weight status $(\mathrm{OR}=2.01$; $95 \% \mathrm{CI}=1.05-3.86 ; \mathrm{p}=0.02)$, low educational level $(\mathrm{OR}=2.01 ; 95 \% \mathrm{CI}=1.05-3.84 ; \mathrm{p}=0.03)$, risky parity or multiparity of more than 2 deliveries $(\mathrm{OR}=1.98 ; 95 \% \mathrm{CI}=1.01-3.86$; $\mathrm{p}=0.03)$, inadequate gestational age $(\mathrm{OR}=1.94$; 95\% $\mathrm{CI}=1.01-3.74 ; \mathrm{p}=0.03)$, respectively.

Multivariate analysis using logistic regression test was performed to evaluate the strongest risk factors that contributed to the occurrence of LBW babies. The result of the test is presented in TABLE 4. 
TABLE 4. Logistic regression analysis of the correlation between iron supplementation, gestational age, parity, and education with LBW babies

\begin{tabular}{|c|c|c|c|c|c|c|}
\hline \multirow[b]{2}{*}{ Characteristics } & \multicolumn{6}{|c|}{ LBW babies occurrence } \\
\hline & $\begin{array}{c}\text { Model } 1 \\
\text { OR } \\
(95 \% \mathrm{CI}) \\
\end{array}$ & $\begin{array}{c}\text { Model } 2 \\
\text { OR } \\
(95 \% \mathrm{CI}) \\
\end{array}$ & $\begin{array}{c}\text { Model } 3 \\
\text { OR } \\
(95 \% \mathrm{CI}) \\
\end{array}$ & $\begin{array}{c}\text { Model } 4 \\
\text { OR } \\
(95 \% \mathrm{CI}) \\
\end{array}$ & $\begin{array}{c}\text { Model } 5 \\
\text { OR } \\
(95 \% \mathrm{CI}) \\
\end{array}$ & $\begin{array}{c}\text { Model } 6 \\
\text { OR } \\
(95 \% \mathrm{CI}) \\
\end{array}$ \\
\hline \multicolumn{7}{|l|}{ Suplementation } \\
\hline - Inapproprate & 2.22 & 2.69 & 2.43 & 2.10 & 2.56 & 3.82 \\
\hline - Appropriale & $1.20-4.08$ & $1.41-5.15$ & $1.29-45.6$ & $(1.12-3.94)$ & $(1.35-4.84)$ & $(1.77-8.22)$ \\
\hline \multicolumn{7}{|l|}{ Hemoglobin Level } \\
\hline - Abnormal & & 2.60 & & & & 3.45 \\
\hline - Normal & & $1.36-4.99$ & & & & $1.59-7.49$ \\
\hline \multicolumn{7}{|l|}{ Gestational Age } \\
\hline - Inadequate & & & 2.16 & & & 2.98 \\
\hline - Adequqte & & & $1.14-4.34$ & & & $1.36-6.51$ \\
\hline \multicolumn{7}{|l|}{ Parity } \\
\hline • Risky & & & & 2.25 & & 2.98 \\
\hline • Non Risky & & & & $1.16-4.34$ & & $1.36-6.51$ \\
\hline \multicolumn{7}{|l|}{ Education Level } \\
\hline - Low & & & & 2.28 & & 2.38 \\
\hline • High & & & & $1.20-4.33$ & & $1.12-5.03$ \\
\hline \multicolumn{7}{|l|}{ Body Mass Index } \\
\hline • Under weight & & & & & 2.35 & 2.27 \\
\hline - Normal & & & & & $1.24-4.44$ & $1.05-4.91$ \\
\hline \multicolumn{7}{|l|}{ Deviance } \\
\hline - (-2 log likelihood) & 234.46 & 225.72 & 228.61 & 223.75 & 227.26 & 198.42 \\
\hline - R2 & 0.03 & 0.06 & 0.05 & 0.07 & 0.06 & 0.18 \\
\hline
\end{tabular}

The analysis conducted for model 1 up to 6 showed a strength of significant correlation in each variable to the occurence of LBW babies. Considering the extent of contribution of each variable that was included simultaneously in logistic regression analysis, the highest change in the OR value was iron supplementation (from the $\mathrm{OR}=2.22 ; 95 \% \mathrm{CI}: 1.15-4.28$ to $\mathrm{OR}=3.82$; 95\% CI: $1.77-8.22$ ), followed by hemoglobin level ( from the $\mathrm{OR}=2.13$; 95\% CI: $1.10-4.11$ to $\mathrm{OR}=3.45 ; 95 \% \mathrm{CI}: 1.59-7.49)$ and gestational age (from the $\mathrm{OR}=1.94 ; 95 \% \mathrm{CI}: 1.01-3.74$ to $\mathrm{OR}=3.11 ; 95 \% \mathrm{CI}: 1.45-6.67)$. Meanwhile, parity showed value of OR $=2.98 ; 95 \% \mathrm{CI}: 1.36$ -6.51 , level of education of OR $=2.38 ; 95 \%$ CI: $1.12-5.03$, and body mass index of OR $=$ 2.27; 95\% CI: $1.05-4.91$.
Among six model that analized, the sixth model showed as the strongest and the most effective model that contributed to the occurrence of LBW babies compare to other model with OR value of 3.82 and $\mathrm{R}^{2}$ value of 0.18 .

\section{DISCUSSION}

The study showed that the occurrence of LBW was associated with ion supplementation. The overall occurrence of LBW babies was more prevalent in babies whose mother not comply iron supplementation program $(<90$ tablets). This result was in accordance with the research conducted by Agtini et al. ${ }^{3}$ that reported pregnant womens who not comply with or not follow the iron supplementation program had 
higher risk of deliver LBW babies. Another study reported that iron supplementation during pregnancy increased the babies birth weight and decreased the incidence of LBW babies. ${ }^{1}$ In addition, it was reported that pregnant women who complied iron supplementation from the early pregnancy until the gestational age of 28 weeks had significantly longer duration of pregnancy, higher birth weight and decrease in the risk of deliver LBW babies compared to those who not complied iron supplementation program.

The high variation of number of iron tablets consumed by pregnant women in Palu was caused by the lacks knowledge of the pregnant women, underutilization of information sources by healthcare providers as well as tolaribility and side effects of iron tablets preparation. Gastrointestinal disturbances such as nausea and vomiting, epigastric pain, constipation, and diarrhea have been reported from the pregnant womens who consumed iron tablets. ${ }^{13}$ These factors caused the low coverage achievement of iron supplementation (83.76\% for $\mathrm{Fe} 1$ and $75.29 \%$ for Fe3) in Palu in 2007. 5 The comprehensive collaboration between pregnant women and healthcare providers is urgently needed to increase the coverage as well as the compliance of pregnant women to follow of iron supplementation program. The need of iron mineral during pregnancy is not enough provided from nutritional resources, therefore the iron supplementation is needed.

Several factors i.e the abnormal hemoglobin level, body unweight status, low educational level, risky parity and inadequate gestanional age have been associated with the incidence of LBW babies in this study. The low hemoglobin level may cause iron deficiency anemia and hypoxia, oxidative stress and infection. Chronic hypoxia may lead to stress that induce the release of corticotropine releasing hormone $(\mathrm{CRH})$ by placenta increasing the risk of LBW babies. ${ }^{9}$
Hemoglobin level can be used as a parameter of iron status that provides a quantitative estimation of the iron level in the body. Pregnant women who have abnormal hemoglobin level $(<11 \mathrm{~g} / \mathrm{dL})$ may experience iron depletion leads to decrease iron transfer to the fetus. It may cause restriction of somatic growth and brain cells, intrauterine fetal death and delivery of LBW babies, which leads to increase morbidity and mortality in pregnancy and perinatal mortality. ${ }^{13}$ Low level of maternal hemoglobin level $(<11 \mathrm{~g} / \mathrm{dL})$ is closely correlated with the incidence of LBW babies and preterm deliveries. ${ }^{14}$ Low level of hemoglobin causes anemia in pregnant women and increases three times higher of LBW babies risk. ${ }^{6}$

Underweight $(\mathrm{BMI}<18.5)$ has been proven increase the incidence of LBW babies in this study. Underweight indicates the lack of nutritional status and caloric supply that affect the weight gain during pregnancy. In addition, under weight is well known as independent predictor for the poor fetal growth and intrauterine growth retardation (IUGR). Low BMI of pregnant women are influenced by nutritional status, low body weight as well as body height. ${ }^{15}$ Anthropometric parameters of pregnant women is correlated with the incidence of LBW babies. ${ }^{16}$ Pregnant women with body weight $<45 \mathrm{~kg}$ have three times higher of LBW babies risk, whereas inadequate nutritional status increases twice times of LBW babies risk. The nutritional status during pregnancy is very important to maintained the health and quality of life of pregnant women. Therefore, it is recommended to increase the nutritional status of pregnant women in order to maintain the health and the well-being of the baby.

Educational status of pregnant women has also been proven influence the incidence of LBW babies in this study. Low educational level increased the incidence of LBW babies. 
This result was in paralel with the previous studies. Low educational level of the mother was reported as one of the risk factors for LBW babies. ${ }^{3,17}$ Moreover, the number of years of education was positively correlated with the incidence of LBW babies. The incidence of LBW babies decreased from $9.2 \%$ for less than 8 years of education to $6.0 \%$ for more than 12 years of education. ${ }^{17}$

Educational status of the mother is an important role in the decrease morbidity and mortality of baby. High educational level increases the access to obtain health informations and healthcare services leads to improve health status of both mother and baby. Liu $e t a l^{18}$ reported that the educational status significantly affected the ability of mother to accept information and it had an exponential correlation with the degree of health. The higher the educational status of the mother, the easier for her to accept the concept of healthy lifestyle independently, creatively, and continuously. The pregnant women with low educational status tend to deliver LBW babies compared to mothers with high educational status.

This research showed that pregnant women with risky parity (multiparity of more than 2 deliveries) had higher risk to deliver LBW babies. It was in accordance with the research conducted by Scholl ${ }^{19}$ that reported that the number of parity and the iron needs was associated with the fetus and placenta growths. Higher the number of parity increases complication during pregnancy, fetal growth restriction and LBW babies. The parity number of $>2$ increased the risk factors during pregnancy and fetal development due to impairment of fetal food distribution and oxygen supply from the mother to fetus. It causes formation of fibrotic tissue on placental vili chorialis that leads to antepartum hemorrhage. Pregnant women who previously had experienced to deliver LBW babies, the occurrence of antepartum hemorrage will be occurred again.
The gestational age was found to be one of the risk factors of LBW babies in this study. Prevous study reported that gestational age was well correlated with the occurrence of LBW babies. ${ }^{17}$ Moreover, the baby who born with inadequate age tends to have LBW, however LBW baby can be born by a mother with adequate age due to IUGR. ${ }^{20}$

Inadequate gestational age is correlated with the impairment fetal growth and development, inadequate nutritional needs of the mother and iron deficiency. It induces stress to both the mother and the fetus that leads to the pregnancy outcome both in term of gestational age and birth weight. The shorter the gestational age, the lower the birth weight of the baby, and it might lead to incomplete organ growth, increased risk of complications, and increased risk of morbidity and mortality of the baby. ${ }^{21} \mathrm{In}$ addition, the LBW baby and inadequate gestational age are caused by mallnutrition of the mother due to infection or unhealthy lifestyle.

Among six model analized using logistic regression model in this study, the model sixth was the model that fulfill the criteria as the strongest and the most effective model that contributed to the occurrence of LBW babies. This result was in accordance previous studies that reported that the iron supplementation to pregnant women decreased anemai incidence which caused the increase of LBW babies risk. Moreover, it is also supported with the report issued by the Department of Health in Palu, Central Sulawesi Province that reported that the coverage of iron supplementation in pregnant woman did not meet the program that targeted $\geq 90$ tablets during pregnancy. ${ }^{5}$ The coverage achievement of $\mathrm{Fe} 1$ and $\mathrm{Fe} 3$ in Central Sulawesi were $83.76 \%$ and $75.29 \%$, respectively. It is believed to be one of the causative factors that contributed to the occurrance of the LBW babies in Palu, Central Sulawesi Province. 
The coverage of antenatal care in Palu, Central Sulawesi Province is relatively success as indicated by the coverage of first visit (K1) was $100 \%$ and K4 was $93.96 \%$. The coverage of $\mathrm{K} 1$ and $\mathrm{K} 4$ are indicators for the standard service of $7 T$ standard of antenatal care. In the $7 T$ standard of antenatal care, the iron supplementation should be performed. If it is well implemented during the antenatal care program, it will decrease the occurrence of LBW babies in Palu. ${ }^{22}$

Good collaboration both pregnant women and healthcare providers should be carried out in the conducting and the monitoring of antenatal care in order to decrease the occurrence of LBW babies in Palu. Pregnant women are expected to be discipline to follow antenatal care especially in following the iron supplementation program. Furthermore, the healthcare providers are expected to be agents to increase the knowledge concerning the important of antenatal care for pregnant women.

\section{CONCLUSION}

In conclusion, iron supplementation during pregnancy that not comply with the program was the strongest risk factor of LBW babies in Palu Central Sulawesi. Pregnant women who no comply with iron supplementation program have 3.82 times higher of LBW babies risk. The occurrence of LBW babies can be reduced by controlling of iron supplementation, hemoglobin level, BMI, gestational age, parity and education. The collaboration between pregnant women and healthcare providers is needed in the conducting and the monitoring of antenatal care in order to decrease the occurrence of LBW babies in Palu.

\section{ACKNOWLEDGEMENTS}

This research could not be conducted without the permission obtained from
Government of Central Sulawesi Province. Authors would like to thank Head of Primary Health Centers in Palu who have supported the study.

\section{REFERENCES}

1. Christian P, Khatry KS, Katz J, Pradhan KE, Leclerq CS, Shrestha RS, et al. Effect of alternative maternal micronutrient supplement and low birth rate in rural Nepal: double blind randomised community trial. USA: Division of Human Nutrition, Johns Hopkins Bloomberg School of Public Health; 2003.

2. WHO. Care of preterm and/or low-birth-weight newbron. [Accessed Jan 8, 2011] Available from: http://www.who.int/maternal_child_adolescent/ topics/newborn/ care_of_preterm/en/

3. Agtini MD, Budiarso RL, Lubis A, Bakri Z, Kristanti CM. Dampak Pemberian tablet zat besi (Fe) pada ibu hamil terhadap kejadian BBLR. Buletin Penelitian Kesehatan 1996; 24(2\&3):2437.

4. United Nations Childrens Fund and World Health Organization Low Birth Weight: country regional ang global estimates. New York: UNICEF \& WHO, 2004.

5. Anonym. Profil kesehatan kota provinsi Sulawesi Tengah. Palu: Pemerintah Provinsi Sulawesi Tengah; 2007.

6. Breymann C. Assessment and differential diagnosis of iron deficiency anemia during pregnancy. Switzerland: Departemen of Obstetri and Gynaecology, Clinic of Obstetrics and Division of Perinatal Physiology, University Hospital of Zurich; 2000.

7. Depkes RI. Pedoman pemberian tablet besi folat \& sirup besi bagi petugas. Jakarta: Dirjen Binkesmas.Depkes RI; 1999.

8. Yip R. Iron supplementation during pregnancy: is it effective? Am J Clin Nutr 1996; 63(6):853-5.

9. Allen LH. Biological mechanisms that might underlie iron's effects on fetal growth and preterm birth. J Nutr 2001; 131(2S-2):581-9.

10. Lubis $Z$. Status gizi ibu hamil serta pengaruhnya terhadap bayi yang dilahirkan. Pengantar falsafah sains, Program Pasca Sarjana/S3, Institut Pertanian Bogor; 2003. 
11. Sastroasmoro S, Ismael S. Dasar-Dasar Metodologi Penelitian Klinis. Jakarta: Binarupa Aksara; 2006.

12. Gordis L. Epidemiology $3^{\text {rd }}$ ed. New York: Philadelpia, WB Sounder Company, 2004.

13. Mahomed K. Iron and folat supplementation in pregnancy. In: Chalmers I, Enkin M, Keirse MLJC eds. London: Oxford University Press (UK), 1989:301-17.

14. Rasmussen K. Is there a causal relationship beetwen iron deficiency or iron-deficiency anemia and weight at birth, length of gestation and perinatal mortality? J Nutr 2001; 131(2S-2):590601 .

15. Anonym. Pedoman pemantauan wilayah setempat kesehatan ibu dan anak (PWS-KIA). Jakarta: Direktorat Jendral Bina Kesehatan Masyarakat \& Direktorat Kesehatan Keluarga. 2004.

16. Ojha N, Malla DS. Low birth weight at term: relationship with maternal anthropometry. JNMA J Nepal Med Assoc 2007; 46(166):52-6.
17. Elshibly EM, Schmalisch G. The effect of maternal anthropometric characteristics and social factors on gestational age and birth weigth in Sudanese newborn infants. BMC Public Health 2008; 18(8):244. DOI: 10.1186/1471-2458-8-244

18. Liu Y, Liu J, Ye R, Ren R, Li S, Li Z. Association of education and occurrence of low birthweight in rural southern China during the early and late 1990s. Am J Public Health 2008; 98(4):687-91.

19. Scholl TO. Iron status during pregnancy: setting the stage for mother and infant. Am J Clin Nutr 2005; 81(5):1218-22.

20. Vijayakumar T, Elisabeth KE, Krishnan V. Umbilical cord blood nutrients in low birth weight babies in relation to birth weight \& gestational age. Indian J Med Res 2008; 128(2):128-33.

21. Saili A. Essential care of low birth weight neonates. Indian Pediatr 2008; 45(1):13-5.

22. Depkes RI. Standar pelayanan kebidanan Departemen Kesehatan Republik Indonesia. Jakarta: Depkes RI; 2003. 